\title{
RECENZJA \\ Peter Sandrini \\ Terminologiearbeit im Recht: Deskriptiver begriffsorientierter Ansatz vom Standpunkt des Übersetzers
}

\author{
Joanna GRZYBEK \\ Instytut Językoznawstwa, Uniwersytet im. Adama Mickiewicza \\ al. Niepodległości 4, 61-874 Poznań \\ joanna.grzybek@gmail.com
}

\begin{abstract}
Książka pod tytułem Terminologiearbeit im Recht: Deskriptiver begriffsorientierter Ansatz vom Standpunkt des Übersetzers napisana przez Petera Sandriniego i wydana w ramach ósmej serii IITF (Internationales Institut für Terminologieforschung) - Międzynarodowego Instytutu Badania Terminologii obejmuje rozważania na temat terminologii języka prawnego i prawniczego. Badania, które wykonał autor, były przeprowadzone w oparciu o prawo kontynentalne i posłużyły do napisania pracy doktorskiej, którą następnie wydano jako publikację książkową.

Praca Sandriniego skierowana jest, jak podkreśla autor, w szczególności do tłumaczy, a w mniejszym stopniu do językoznawców. Dotyczy przekładu tekstów z zakresu prawa i tworzenia baz terminologicznych, które miałyby ułatwić proces tłumaczenia. Punktem wyjścia dla autora jest teza stanowiąca o tym, że tłumacz tekstów specjalistycznych uczestniczy przede wszystkim w procesie transferu kulturowego, a nie jakby się wydawało językowego (Sandrini, 1996, s. 8).

Rozdział pierwszy pod tytułem Fachsprache Recht dotyczy języka prawa jako języka specjalistycznego. Zdaniem Sandriniego głównym czynnikiem odróżniającym język specjalistyczny (Fachsprache) od języka ogólnego (Gemeinsprache) jest terminologia specjalistyczna (Fachwortschatz). Początkowo badanie języków specjalistycznych miało na celu poznanie przede wszystkim terminologii fachowej. Później zainteresowano się również cechami syntaktycznymi i gramatycznymi. Terminologia języka specjalistycznego nie zawsze różni się od terminologii języka ogólnego. Czytelnikowi nasuwają się w trakcie czytania spostrzeżenia innych osób badających język prawny i prawniczy. Przykładowo zdaniem Bożeny Hałas język prawa jest najczęściej analizowany metodami logicznymi, a aparat pojęciowy ewentualnych badań nad językiem jest zwykle związany ze słownictwem charakterystycznym dla semiotyki logicznej (np. norma, prawda, analogia, indukcja) (Hałas, 1995, s. 195). Badaniem słownictwa polskich tekstów aktów prawnych zajmuje się Agnieszka Choduń. Klasyfikując terminologię języka prawa, przyjęła ona podział Andrzeja Markowskiego, który w obrębie odmian leksykalnych polszczyzny zaproponował rozróżnienie na słownictwo swoiste i słownictwo wspólne (wspólnoodmianowe). Słownictwo swoiste to takie, które odróżnia daną odmianę od innych odmian językowych polszczyzny, czyli leksyka zawodowa i terminologiczna, leksyka nacechowana ekspresywnie, np. gwary środowiskowe oraz leksyka erudycyjna, czyli urzędowa i książkowa. Natomiast słownictwo wspólne to polszczyzna, która może być używana we wszystkich
\end{abstract}




\section{Legilingwistyka Porównawcza 3/2010}

wymienionych powyżej odmianach leksykalnych języka. Według spostrzeżeń Markowskiego, słownictwo to jest nieerudycyjne, niespecjalistyczne i nieekspresywne, a więc neutralne (Choduń, 2007, s. 108).

Sandrini opisuje podział języka fachowego sporządzony przez Hoffmanna (1985, s. 66) w oparciu o kryterium poziomów abstrakcji. Poziomy abstrakcji tekstów specjalistycznych różnią się od siebie przede wszystkim stopniem natężenia użycia terminów fachowych. Najwyższym poziomem abstrakcji charakteryzują się teoretyczne nauki podstawowe. Językiem fachowym na tym poziomie, nazywanym przez Sandriniego poziomem A-1, posługują się komunikujący się między sobą naukowcy. Cechą charakterystyczną tej odmiany języka są symbole sztuczne. Z kolei poziom B-1 charakteryzuje się bardzo wysokim poziomem abstrakcji, zastosowaniem symboli sztucznych oraz języka naturalnego. Język należący do tej kategorii stosowany jest w naukach eksperymentalnych, w komunikacji pomiędzy naukowcami technikami oraz pomiędzy nimi i ich pomocnikami naukowo-technicznymi. Następnym wyodrębnionym poziomem jest poziom $\mathrm{C}-1$, który cechuje się językiem naturalnym z bardzo dużym udziałem terminologii specjalistycznej i silnie zdeterminowaną składnią. Język taki używany jest $\mathrm{w}$ naukach stosowanych i technice. Jego cechą jest wysoki poziom abstrakcji i dość swobodna składnia. Użytkownicy języka z poziomu C-1 zaliczają się do naukowców (techników) oraz kierowników naukowych i kierowników technicznych produkcji. Poziom czwarty D-1 o niskim stopniu abstrakcji obejmuje język naturalny, charakteryzujący się swobodną składnią i dużą ilością terminów fachowych. Język tego poziomu używany jest przez naukowych i technicznych kierowników produkcji oraz zatrudnionych fachowców. Najniższy stopień abstrakcji występuje na poziomie E-1, który dotyczy języka naturalnego uzupełnionego w niewielkim stopniu przez terminy specjalistyczne. Użytkownicy języka poziomu E-1 to porozumiewający się nawzajem ze sobą przedstawiciele producenta, przedstawiciele handlowi i konsumenci (Sandrini, 1996, s. 6-7).

W oparciu o powyżej wspomniany podział Hoffmanna, Sandrini sporządza ciekawą klasyfikację języka prawa. W rzeczywistości prawnej poziom A-1 nie występuje. Poziom o bardzo wysokim stopniu abstrakcji - poziom B-1, zawiera interpretacje i komentarze do tekstów ustawowych, tworzone przez ekspertów z zakresu prawa i profesorów uniwersyteckich. Wysokim poziomem abstrakcji cechują się między innymi dokumenty, umowy, ustawy zaszeregowane do poziomu C-1. Języka tego używają sędziowie w komunikacji z adwokatami, adwokaci między sobą, ustawodawcy i komisje ustawodawcze. Z kolei adwokaci komunikujący się z oskarżonymi posługują się językiem naturalnym, urozmaiconym dużą ilością terminologii fachowej i stosunkowo swobodną składnią. Język wypowiedzi tych osób zaszeregowano do poziomu D-1, o niskim stopniu abstrakcji. Językiem naturalnym z małą ilością terminów fachowych, o swobodnej składni jest język na poziomie E-1, którym posługują się komunikujący się ze sobą obywatele i adwokaci, obywatele i politycy oraz obywatele między sobą. Język o niskim poziomie abstrakcji jest również typowy dla dziennikarzy i polityków zajmujących się tematyką prawniczą (Sandrini, 1996, s. 13-14).

W pierwszym rozdziale omawianej tu książki Sandrini stawia śmiałą i ciekawą tezę stanowiąca o tym, że nie istnieje ogólny język prawa. Język prawa obejmuje bowiem wiele narodowych języków prawa, które w mniejszym lub większym stopniu różnią się 
od siebie. Języki te kształtowane są przez porządek prawny, który je otacza. Jeden system prawny może zawierać kilka języków. Jako przykłady autor podaje państwa kilkujęzyczne, takie jak Szwajcaria i Belgia. Różne systemy prawne mogą również używać tego samego języka. $Z$ faktem takim spotykamy się w Austrii, Niemczech i Szwajcarii, w których to państwach obowiązuje język niemiecki. Tłumaczenie tekstów $\mathrm{z}$ zakresu prawa nie oznacza więc thumaczenia $\mathrm{z}$ jednego języka na inny język, ale z języka określonego systemu prawnego na język innego systemu prawnego (Sandrini, 1996, s. 16). Nie trudno się nie zgodzić z powyższymi poglądami autora książki. Należy jednak pamiętać, że pewnym stopniem ogólności wyróżnia się na przykład prawo wspólnotowe. Język prawa Unii Europejskiej obejmuje cechy języków poszczególnych państw tworzących wspólnotę, prawodawców wywodzących się z różnych państw.

Sandrini niejednokrotnie podkreśla zależność przekładu od celu, czyli skoposu. W oparciu o teorię skoposu Reiss i Vermeera thumacz najpierw określa odbiorcę tekstu docelowego, a następnie dobiera odpowiednią metodę thumaczeniową. Oznacza to, że tłumacz powinien znać rzeczywistość prawną, w której żyje odbiorca translatu, jak również mieć świadomość, jaką funkcję ma pełnić przetłumaczony tekst. Tłumaczenie dla odbiorcy bliskiego systemowi austriackiemu powinno uwzględniać terminologię austriackiego języka prawa. Analogicznie do powyższego, odbiorca niemiecki powinien otrzymać thumaczenie zawierające niemiecką terminologię prawną, a szwajcarski szwajcarską. Uwagę warto też zwrócić na język angielski, który w wielu krajach jest językiem państwowym, czy francuski, który dotyczy francuskiego, szwajcarskiego, belgijskiego i kanadyjskiego języka prawa (Sandrini, 1996, s. 17). Myśl Sandriniego można by rozwijać, porównując na przykład język chiński używany w Chinach kontynentalnych, na Tajwanie oraz w Hong Kongu. Mieszkańcy wymienionych Chin i Tajwanu posługują się różnymi systemami pisma, odpowiednio znakami uproszczonymi i znakami pełnymi. Różna jest również niekiedy terminologia języka prawnego i prawniczego stosowanego w Chinach kontynentalnych, na Tajwanie czy w Hong Kongu.

Sandrini wyróżnia trzy rodzaje thumaczenia, cytowane już od dawna przez teoretyków języka prawa, w Polsce przez Urszulę Topczewską (1998), a następnie Danutę Kierzkowską (2002, s. 46):

1. „Bardzo wierne oddanie w języku docelowym pojęć funkcjonujących w systemie prawnym języka wyjściowego, tak aby odbiorca nie identyfikował ich ze znanymi mu pojęciami własnego, zwykle odmiennego systemu prawnego. Zastosowane przez tłumacza środki językowe powinny wyraźnie sygnalizować różnice między obydwoma systemami. Celem takiego thumaczenia jest dokładne przekazanie odbiorcy informacji wyrażonych w tekście wyjściowym, co w przypadku thumaczeń prawnych jest najczęściej występującym celem".

2. „Tłumaczenie oddziałujące na odbiorcę terminalnego w taki sam sposób jak na odbiorcę prymarnego. Tekst thumaczenia pełni wówczas taką funkcję jak tekst oryginału i służy wytworzeniu u odbiorcy pożądanych postaw i zachowań. Ten rodzaj thumaczenia tekstów prawnych stosowany jest tylko w wyjątkowych przypadkach, np. przy tłumaczeniu zarządzeń, zaleceń i przepisów prawnych dla mniejszości językowych w danym państwie”. 


\section{Legilingwistyka Porównawcza 3/2010}

3. „Tłumaczenie wiernie oddające treść tekstu oryginalnego (tak aby odbiorca nie mylił użytych przez tłumacza terminów z terminami charakterystycznymi dla porządku prawnego, z którym styka się na co dzień), a równocześnie jednakowo odbierane przez wszystkich użytkowników języka docelowego, niezależnie od tego jaki system prawny jest im znany. Ten rodzaj tłumaczenia stosuje się w przypadku tłumaczeń tekstów $\mathrm{z}$ zakresu prawa europejskiego lub międzynarodowego, które funkcjonują jako prawo niezależne od jakiegokolwiek państwowego porządku prawnego".

Zgodnie z tym, co pisze Sandrini, przed przystąpieniem do przekładu, thumacz powinien zatem postawić sobie pytanie, czy przekład ma informować o rzeczywistości prawnej języka wyjściowego i czy ma służyć takiemu samemu celowi, jak tekst wyjściowy. Niektóre tłumaczenia mogą być celowo niezależne od systemów prawnych, np. te dotyczące prawa wspólnotowego czy międzynarodowego. Sandrini niejednokrotnie cytuje Gerard-Rene de Groot (1991), który podkreśla nierozłączność tłumaczenia terminologii prawnej i porównywania systemów prawnych języka wyjściowego i języka docelowego. Wspomina on również o konieczności określenia funkcji tekstu docelowego. Do celu thumaczenia powinno się bowiem dostosować strategię thumaczenia (Sandrini, 1996, s. 21).

Drugi rozdział omawianej tu książki Płaszczyzna kognitywna poświęcony jest rozważaniom na temat terminów w ogóle, a w szczególności na temat pojęcia prawnego. Podkreślana jest w nim rozłączność językoznawstwa i nauki o thumaczeniu. Przedmiotem tej drugiej nie jest bowiem język jako środek komunikacji, ale treść komunikatu. Podstawowym elementem czynności kognitywnej i przez to również komunikacji jest termin. Jak wiadomo, termin użyty w nauce prawa nie służy jedynie komunikacji, ale regulacjom poszczególnych dziedzin życia. Dlatego też pojęcia prawne powinno się definiować z odpowiednią precyzją. Poszczególni autorzy tekstów dzielą pojęcia prawne na grupy. Rolf Wank (1985) wyróżnia w tekstach prawnych pojęcia ogólne wywodzące się $\mathrm{z}$ języka codziennego (Allgemeinvorstellungen), sekundarne pojęcia prawne (sekundären Rechtsbegriffen), czyli pojęcia relewantne prawnie oraz prymarne pojęcia prawne (primären/echten Rechtsbegriffen), o znaczeniu typowo prawnym. Zdaniem Wanka dobierając pojęcia powinno się rozróżniać pojęcia fachowe od tych, które tylko wspierają język prawa (1985, s. 25-26). Ponadto, jak pisze za Wankiem (1985) Sandrini, ważne jest określenie pochodzenia poszczególnych pojęć prawnych. Wyróżnia się pojęcia legislacyjne (Legalbegriffe) i dotyczące normy prawnej (Rechtssatzbegriffe), sformułowane przez ustawodawcę oraz pojęcia zawierające treści prawne (Rechtsinhaltsbegriffe) i pojęcia dogmatyczne (Dogmatikbegriffe/rechtswissenschaftliche Begriffe) tworzone przez prawników. Druga grupa pojęć prawnych podporządkowana jest dyskursowi naukowemu i nie powinna być zdaniem Sandriniego brana pod uwage w pracy nad terminologią (Sandrini, 1996, s. 25-26). Autor książki porusza również kwestię zależności pojęcia prawnego od stanu faktycznego, do którego się ono odnosi. W kontekście prawa materialnego czynniki semantyczno-językowe odgrywają, jeśli w ogóle, podrzędną rolę. Cechy pojęć prawnych odpowiadają dokładnie cechom prawnego stanu faktycznego. W odniesieniu do pojęć prawa formalnego lub do pojęć określających osoby, organy i dokumenty mówi się o prawnym języku specjalistycznym. W takiej sytuacji stan faktyczny nie jest wyrażany przez jedno pojęcie, ale przez kilka 
pojęć, w formie zdania czy paragrafu (Sandrini, 1996, s. 29-30). W pracy nad terminologią ważną rolę odgrywają cechy pojęć, które opisuje i analizuje autor w rozdziale drugim. Porusza on na przykład kwestię funkcji i autorów definicji. Definicje służą ustaleniu co powinno być rozumiane przez dane pojęcie. Ponadto tworzą podstawy tworzenia nazwy pojęcia, struktury systemu pojęciowego i służą określeniu ekwiwalencji (Sandrini, 1996, s. 36). To cechy tworzące zakres pojęcia pozwalają na odróżnienie danego pojęcia prawnego od innego. Ustalane są one niezależnie od języka przez ekspertów z danej dziedziny, a w przypadku prawa przez ustawodawców lub sądy. Oczywiście ustalenia takie są ograniczone w czasie i obowiązują do czasu, gdy społeczne, socjalne czynniki nie spowodują nowej interpretacji danej normy (Sandrini, 1996, s. 42). Z kolei w punkcie trzecim rozdziału drugiego Sandrini opisuje różne określenia definicji oraz różne funkcje definicji. Podanie zawartości (Begriffsinhaltes) lub zakresu danego pojęcia pozwala odróżnić go od innych pojęć i zapewnić zrozumienie definiowanego pojęcia $\mathrm{w}$ obrębie komunikacji określonego obszaru specjalizacyjnego (Fachgebietes). Z kolei językowe zdefiniowanie pojedynczych tworzących dane pojęcie cech umożliwia najpierw intralingwalne, a następnie interlingwalne porównanie pojęć. Takie definicje służą przedstawieniu możliwie jednoznacznego związku pomiędzy pojęciami i ich nazwami (Sandrini, 1996, s. 49). Znaczącym spostrzeżeniem autora jest to, że definicje pojęć prawnych wyróżniają się spośród innych faktem, iż obowiązują zwykle tylko na określonym obszarze i przez określony czas. Bywa, że dotyczą tylko jednej ustawy. Niektóre $\mathrm{z}$ nich mogą być w pewnych granicach rozszerzane lub ograniczane (Sandrini, 1996, s. 54). Sandrini uważa, że definiowanie pojęć prawnych nie powinno polegać na określaniu leksemów, ale przedstawianiu związku pomiędzy danym pojęciem a jego językową formą reprezentacji. Definicja powinna być utworzona niezależnie od języka, ale za pomocą języka i odpowiedniej wiedzy (Sandrini, 1996, s. 59-60). Ustawodawca regulujący określone sytuacje życiowe posługuje się określonymi pojęciami. Wszystkie one muszą zostać odpowiednio zdefiniowane (Sandrini, 1996, s. 62). Podczas czytania o definiowaniu pojęć prawnych, polskiemu czytelnikowi nasunąć się może praca Choduń, w której zwraca się uwagę na takie jednostki leksykalne, które w słownikach nie są traktowane jako terminy, ale mogą być za terminy uznane, czyli tak zwane definicje legalne, zawarte w tekstach aktów prawnych (Choduń, 2007, s. 124-128). Prawodawca nadaje danym wyrazom lub wyrażeniom w definicjach legalnych określone znaczenia, przy czym wyrazy mogą być różnie definiowane $w$ różnych ustawach. Przykładowo definicja wyrazu młodociany w Kodeksie pracy jest inna niż w Kodeksie karnym skarbowym. Kodeks pracy podaje, że „młodocianym w rozumieniu kodeksu jest osoba, która ukończyła 16 lat, a nie przekroczyła 18 lat”, a Kodeks karny skarbowy, że „młodociany jest to osoba, która w czasie popełnienia czynu zabronionego nie ukończyła 21 lat $\mathrm{i}$ w czasie orzekania w pierwszej instancji 24 lat" (Choduń, 2007, s. 129).

Kolejną, mniej ciekawą kwestią poruszaną w rozdziale drugim książki jest uporządkowanie pojęć prawnych (Begriffsordnung) - czynność niezbędna w pracy terminologicznej. Pojęcia są bowiem zawsze częścią jakiegoś obszaru wiedzy. Nie są samoistne, a często są od siebie zależne. W systemach pojęciowych można wyróżnić pojęcia nadrzędne i pojęcia podrzędne. Sandrini opisuje metody porządkowania pojęć prawnych, a następnie ich klasyfikację. Podaje również przykładowe klasyfikacje 


\section{Legilingwistyka Porównawcza 3/2010}

terminów z zakresu prawa, tj. Eurodicautom: Lenoch Klassifikationssystem oraz Terminium: Klassifikationssystem (Sandrini, 1996, s. 95-122).

W rozdziale trzecim autor książki skupia się na niedługo na płaszczyźnie językowej pojęć prawnych. Ponieważ nie ma on w omawianej pracy na celu badania terminów od strony językowej, rozdział ten zawiera jedynie ogólne, wprowadzające spostrzeżenia dotyczące zależności pomiędzy pojęciem a jego znakiem językowym. Dyskusja językoznawców dotycząca znaczenia znaku językowego jest różnorodna. Sandrini przypomina o koncepcjach de Saussure'a, amerykańskiego strukturalizmu, brytyjskiego kontekstualizmu i semantyki strukturalnej. Jak podkreślano w poprzednich rozdziałach, nauka o terminologii (Terminologielehre) rozróżnia niezależne od języka pojęcie (Begriff) i przyporządkowaną mu nazwę (Benennung), czyli znak językowy (sprachliches Zeichen). Pojęcia mogą być również wyrażane przez symbole, formuły, rysunki i opisy. Nierzadko jedno pojęcie wyrażane jest przez różne nazwy, mamy wtedy do czynienia z synonimią. Ograniczoność środków językowych powoduje z kolei polisemię i homonimię. Spostrzeżenia Sandriniego dotyczą również metod tworzenia nazw, czy to w formie neologizmów, czy poprzez kompozycję, derywację, konwersję, skrócenie wyrazu.

Najciekawiej wypada niewątpliwie czwarty rozdział książki, który dotyczy wielojęzykowej pracy terminologicznej (Multilinguale Terminologiearbeit). Porównanie specyficznych dla różnych systemów prawnych terminów nie należy, jak się okazuje w praktyce do łatwych czynności. Tłumacz ma za zadanie przede wszystkim ustalić funkcję tekstu docelowego oraz rodzaj odbiorcy tekstu. Od nich zależy dobór terminologii. Jak wspomina Sandrini, tłumaczenia w oparciu o parę językową tego samego systemu prawnego (np. systemu prawnego w Szwajcarii i Belgii) różnią się znacznie od thumaczeń $\mathrm{w}$ różnych językach, które związane są z różnymi systemami prawnymi. Dla czytelnika nieznającego języka niemieckiego i języka włoskiego rozważania Sandriniego mogą wydawać się niestety uboższe, z tego względu, że niezrozumiałe są podawane przez niego przykłady w języku niemieckim i włoskim. Autor opisuje wprowadzanie języka prawa niemieckiego do włoskiej rzeczywistości prawnej w południowym Tyrolu (Sandrini, 1996, s. 133). Praca terminologiczna, a w końcu praca nad terminografią polega jego zdaniem na porównywaniu pojęć i zawartości terminów wywodzących się z różnych rzeczywistości prawnych.

Ekwiwalencja w tłumaczeniu może występować na poziomie pojęć prawnych lub na poziomie tekstu (Sandrini, 1996, s. 136). Każdy system prawny dysponuje specyficznym aparatem terminologicznym. Ekwiwalencja poszczególnych pojęć prawnych jest zależna od czynników kulturowych, historycznych i językowych. Pojęcia prawne stanowią części składowe reguł prawnych lub nazwy instytucji prawnych. Zgodnie z przytoczonymi przez Sandriniego spostrzeżeniem de Groot (1991), nie jest możliwa ekwiwalencja absolutna, gdy język wyjściowy i język docelowy związane są z różnymi rzeczywistościami prawnymi. Terminy pozornie identyczne różnią się w poszczególnych systemach prawnych często zakresem znaczeniowym. Sandrini podaje na potwierdzenie tej tezy przykłady pojęć prawnych funkcjonujących w systemie prawnym Austrii i Włoch (Sandrini, 1996, s. 140).

Tłumacze często orientują się, że w rzeczywistości prawnej języka docelowego nie istnieją pojęcia prawne, które odpowiadałyby pojęciom języka wyjściowego. 
Czynności, jakie wykonuje się w takich sytuacjach obejmują: oszacowanie podobieństw w regulacjach dotyczących określonej instytucji czy sytuacji w rzeczywistości prawnej języka docelowego, określenie odbiorcy tekstu docelowego i dobór strategii tłumaczenia (Sandrini, 1996, s. 143). Ciekawym problemem poruszonym przez Sandriniego jest kwestia systemu prawnego, w którym funkcjonuje kilka języków, jak np. system prawny Kanady, Belgii czy Szwajcarii. Omówiona w książce sytuacja dotyczy jeszcze innego obszaru prawnego, tj. południowego Tyrolu. W przypadku, gdy tamtejsze włoskie regulacje prawne tłumaczy się na język niemiecki, używa się istniejących już terminów języka niemieckiego, mających zastosowanie w niemieckim czy austriackim systemie prawnym. Jeżeli takowych nie ma, rozwiązaniem jest jedynie ukucie nowego terminu w języku niemieckim. Przejęcie terminu specjalistycznego z jednego do drugiego języka może jedynie skutkować nieporozumieniami. Okazuje się, że niektóre używane w Tyrolu terminy mają tę samą wymowę i formę jak w systemie prawnym języka niemieckiego. Znaczenia terminów jednak nie zawsze w pełni się pokrywają. Odbiorca, któremu bliskie jest prawo niemieckie, może odnieść dany termin do rzeczywistości prawnej Niemiec, nawet jeśli znaczenie użytego $\mathrm{w}$ południowym Tyrolu terminu związane jest $\mathrm{z}$ prawem włoskim.

Zdaniem Sandriniego, porównywanie systemów prawnych może ułatwić nauka o systemach prawnych (Rechtskreislehre), która pozwala na pogrupowania systemów prawnych o wspólnych cechach. Jak wiadomo, podział systemów prawnych świata nie jest ustalony. Większość badaczy prawa i jego języka spotkała się na pewno z odmiennymi klasyfikacjami systemów prawnych. Na przykład Roman Tokarczyk proponuje podział na: kulturę prawa stanowionego, kulturę common law, kulturę prawną judaizmu, kulturę prawną chrześcijaństwa, kulturę prawa europejskiego, kulturę prawną islamu, kulturę prawną hinduizmu, kulturę prawną buddyzmu, kulturę prawną konfucjanizmu i kulturę prawną animizmu (Tokarczyk, 2005, s. 6-8).

Jak zaznacza wspaniałomyślnie autor recenzowanej publikacji, zestawienie systemów prawnych może się odbywać na poziomie makro oraz na poziomie mikro. Porównanie typu makro dotyczy ogólnie pojmowanych systemów prawnych i kręgów prawnych. Natomiast porównanie typu mikro obejmuje normy prawne i instytucje prawne (Sandrini, 1996, s. 154). Wyniki porównania typu makro pozwalają na doskonalsze porównanie typu mikro, które odgrywa znaczną rolę w pracy dotyczącej terminologii prawnej. Sandrini omawia metodykę porównywania systemów prawnych w kontekście pracy nad terminologią. Posługuje się modelem Kurt Hans von Eberta (1978), rozszerzonym o koncepcje Maxa Rheinsteina (1987). Model dotyczy poznania i normatywnego określenia reguły prawnej. Zwraca się uwagę na źródła prawa i zwyczaje w poszczególnych systemach prawnych oraz na podobieństwa i różnice w strukturze i funkcji poszczególnych reguł prawnych. Interesującym i słusznym postulatem jest tu twierdzenie, że prawo powinno być pojmowane w kontekście socjologicznym. Określenie zależności pomiędzy środowiskiem a prawem umożliwia tak naprawdę law in action, czyli prawo aktualnie praktykowane (Sandrini, 1996, s. 164). Uwaga ta jest szczególnie istotna $\mathrm{w}$ przypadku terminologii prawnej, a więc i lingua legis. Jak wiadomo, prawo zmienia się niemal każdego dnia. Porównanie terminów w kontekście law in action pozwala na stwierdzenie ekwiwalencji funkcjonalnej i równowartości funkcji norm prawnych różnych systemów prawnych. Inne znaczenie ma 


\section{Legilingwistyka Porównawcza 3/2010}

regulacja prawna w systemie prawa kontynentalnego, inne w tzw. rzeczywistości prawa socjalistycznego, gdzie większą moc sprawczą ma polityka i gospodarka (Sandrini, 1996, s. 164). Przykładem spoza ksiązki Sandriniego może być nie do końca identyczne pojęcie własności prywatnej w Europie i w Chinach. W Chinach do 2007 roku własność prywatna nie była prawnie chroniona. Nawet dziś chłop mający na własność mieszkanie na wsi może być w każdej chwili wywłaszczony z ziemi, która jest własnością państwa.

Po rozważaniach dotyczących porównania systemów prawnych oraz ekwiwalencji, w trzeciej części rozdziału czwartego nadchodzi kolej na omówienie sposobów tworzenia pozwalającej na porównanie systemów prawnych pracy terminologicznej (Terminologiearbeit). Sandrini podaje thumaczom przepis na ułatwienie procesu tłumaczenia. Jego zdaniem praca terminologiczna nie mogłaby być pracą jednego tylko thumacza, ale najlepiej odpowiedniej instytucji czy komisji zajmujących się terminologią (Terminologiekommissionen). Badanie terminologii powinno być podzielone $\mathrm{w}$ oparciu o określone dziedziny prawne i określoną tematykę. $\mathrm{W}$ rozdziale tym omawia się ponadto gromadzenie dokumentów i innych materiałów, dokumentowanie i porządkowanie poszczególnych elementów prawa, określenie stosunków pomiędzy systemami prawnymi, a na końcu porównanie określonych pojęć.

Ostatnia część recenzowanej książki dotyczy terminografii. Piąty rozdział książki jest jakby celem jej napisania, a poprzedzające go rozdziały wydają się być do niego wstępem. Sandrini zdradza, że zestawienie porównawcze terminologii specyficznych systemów prawnych wynika z trudności, z którymi miał do czynienia podczas pisania pracy dyplomowej. W pracy tej autor próbował oddać terminologię dotyczącą włoskiego prawa poprzez terminologię niemiecką. Stąd w publikacji tak duża liczba przykładów z tłumaczenia terminów włoskich na język niemiecki. Język niemiecki jest zresztą ciekawym językiem, wymagającym od posługujących się nim thumaczy znajomości kultury nie tylko Niemiec, ale i innych krajów niemieckojęzycznych. Jak pisze Sandrini, aby utworzyć niemiecką terminologię języka prawa, należy wziąć też pod uwagę odpowiednie terminy w austriackim, niemieckim i szwajcarskim języku prawa (Sandrini, 1996, s. 197). Tłumacz powinien więc, jak słusznie podkreśla autor, mieć świadomość, jak określona dziedzina prawna uregulowana jest $\mathrm{w}$ innym systemie prawnym, jakie będzie potrzebować pojęcia oraz jakich terminów powinien użyć, by trafić tekstem do adresata tak, jak oryginał trafiał do odbiorców w języku oryginału.

Według Sandriniego pomoce terminologiczne powinny wspomagać pracę thumacza. Czy zawsze jednak spełniają one swoje funkcje? Autor analizuje thumaczenie kilku terminów włoskich i niemieckich w oparciu o słowniki jednojęzyczne oraz dwujęzyczne specjalistyczne. Jak wykazuje jego analiza, specjalistyczne słowniki jednojęzyczne są bardziej przydatne tłumaczom niż obszerne słowniki dwujęzyczne. Tłumaczenie jednak powinno być, jak pisze za Mary Snell-Hornby Sandrini, zależne od tekstu i współmierne z kontekstem, a słowniki powinny tylko pomagać w ustaleniu odpowiedniego ekwiwalentu, a nie podawać odpowiedniki, które łatwo wstawić do tekstu (Sandrini, 1996, s. 203).

Terminografia $\mathrm{w}$ praktyce objawia się $\mathrm{w}$ terminologicznych bankach danych (Terminologiedatenbanken). Obecnie istnieje wiele banków danych $\mathrm{z}$ terminologią. Sandrini podaje przykłady i opisuje krótko TEAM i Eurodicautom oraz inne programy komputerowe do zarządzania zebranymi danymi. Nadmienia również o systemach 
zarządzających terminologią i terminografią w Unii Europejskiej. Porusza problem książek dotyczących języka prawa i języka zarządzania. Obecnie obserwuje się zapotrzebowanie na mniejsze bazy danych, które ograniczone są tylko do jednej dziedziny lub mniejszego obszaru wiedzy (Sandrini, 1996, s. 222). Ostatnie strony książki mogą nużyć tłumacza niezainteresowanego samym tworzeniem terminologicznej bazy danych. Sandrini tworzy model takiej bazy dla dziedziny prawa. Opisuje jej strukturę, analizując kategorie danych, strukturę wpisów (np. teminologiczne, bibliograficzne), zależności pomiędzy systemami prawnymi, homonimię i synonimię, frazeologię i kolokacje. Ponadto, zagłębia się w problem systemów baz danych. Otrzymujemy zatem model terminologicznej bazy danych, który mógłby ułatwić pracę tłumaczom. Po lekturze książki Sandriniego, zdawałoby się, że nie pozostaje nam thumaczom tekstów specjalistycznych nic innego, jak utworzyć ten nowy typ pomocy naukowej. Przede wszystkim jednak polecam Terminologiearbeit im recht. Deskriptiver begriffsorientierter Ansatz vom Standpunkt des Übersetzers wszystkim thumaczom, którzy chcieliby szerzej i świadomiej spojrzeć na terminologię thumaczonych tekstów z zakresu prawa. Lektura niewątpliwie wpłynie dodatnio na jakość wyników ich pracy. Omawiana książka, mogłaby również zasilić kanon lektur studentów zgłębiających teorię przekładu i literaturę polecaną nie tylko adeptom tłumaczenia, ale również doświadczonym tłumaczom.

\section{Bibliografia}

Choduń Agnieszka, 2007, Stownictwo tekstów aktów prawnych $w$ zasobie leksykalnym wspótczesnej polszczyzny, Warszawa, Wydawnictwo TRIO.

Ebert Kurt Hans, 1978, Rechtsvergleichung, Bern, Stämpfli \& Cie.

Groot Gerard-Rene de, 1991, Recht, Rechtssprache und Rechtssystem. Betrachtungen über die Problematik der Übersetzung juristischer Texte, „Terminologie \& Traduction", nr 3, s. 279-316.

Hałas Bożena, 1995, Terminologia języka prawnego, Zielona Góra, Wyższa Szkoła Pedagogiczna im. Tadeusza Kotarbińskiego.

Hoffmann Lothar, 1985, Kommunikationsmittel Fachsprache. Eine Einführung, Tübingen, Gunter Narr.

Kierzkowska Danuta, 2002, Ttumaczenia prawnicze, Warszawa, Wydawnictwo TEPIS.

Markowski Andrzej, 1987, Miejsce słownictwa wspólnego wśród odmian leksykalnych polszczyzny, „Poradnik językowy”, z. 7, s. 514.

Markowski Andrzej, 1987, Wyodrębnianie wyrazów wspólnych z zasobu leksykalnego polszczyzny, „Poradnik językowy”, z. 8, s. 585.

Reiss Katharina, Vermeer Hans, 1991, Grundlegung einer allgemeinen Translationstheorie, Tübingen, Niemeyer.

Rheinstein Max, 1987, Einführung in die Rechtsvergleichung, München, C.H. Beck.

Sandrini Peter, 1996, Terminologiearbeit im recht. deskriptiver begriffsorientierter Ansatz vom Standpunkt des Übersetzers, IITF-Series 8, Vienna, TermNet.

Saussure Ferdynand de, 2002, Kurs językoznawstwa ogólnego, Warszawa, Wydawnictwo Naukowe PWN. 


\section{Legilingwistyka Porównawcza 3/2010}

Snell-Hornby Mary, 1990, Dynamics in meaning as a problem for bilingual lexicography, [w:] Meaning and Lexicography. Linguistic \& Literary Studies in Eastern Europe (LLSEE), red. J. Tomaszczyk, B. Lewandowska-Tomaszczyk Barbara, Amsterdam/Philadelphia, John Benjamins, s. 224.

Tokarczyk Roman, 2005, Wspótczesne kultury prawne, Kraków, Kantor Wydawniczy Zakamycze.

Topczewska Urszula, 1998, Ttumaczenie terminologii prawnej i prawniczej w ujęciu Sandriniego, „Lingua Legis”, nr 6.

Wank Rolf, 1985, Die juristische Begriffsbildung. Schriften des Instituts für Arbeits- und Wirtschaftsrecht der Universität zu Köln, t. 48/I, München, C.H. Beck. 